\title{
Comparative Study between the Outcomes of Posterior Lumbar Interbody Fusion Combined with Transpedicular Screws versus Transpedicular Screws Alone in Recurrent Lumbar Disc Prolapse
}

\author{
Mohamed Elgibali Ahmed ${ }^{1 *}$ MD; Abdallah Mohamed Abdel Wahab Salama ${ }^{1}$ MD; \\ Mohamed Hosam El-Dien Abo-Shahba ${ }^{1}$ MSc
}

*Corresponding Author:

Mohamed Elgibali Ahmed

m.gebali@domazhermedicine.edu.eg

Received for publication July 11,2021;Accepted August 22, 2021;

Published online August 22, 2021.

Copyright The Authors published by Al-Azhar University, Faculty of Medicine, Cairo, Egypt. Users have the right to read, download, copy, distribute, print, search, or link to the full texts of articles under the following conditions: Creative Commons AttributionShare Alike 4.0 International Public License (CC BY-SA 4.0).

doi: $10.21608 /$ aimj.2021.82238.1512

\section{${ }^{I}$ Neurosurgery Department}

Faculty of medicine, Al-Azhar university, Dameitta, Egypt.

\section{ABSTRACT}

Background: Recurrent lubmer disc herniation is a challenge facing neurosurgeons. Disectomy is the rule. However, fusion was emerged as an alternative. No consensus for standard fusion technique is reached yet. Aim of the work: to investigate the outcome of posterior interbody fusion combined with transpedicular screws versus the transpedicular screws alone, for recurrent disc herniation.

Patients and Methods: Thirty patietns with recurrent disc prolapse were included and divided into two equal groups. Group A: interbody fusion with transpedicular screw, and Group B: transpedicular screws alone). All were evaluated by history taking, clinical examination and laboratory and radiological investigations. Pain assessed by visual analogue scle and oswestry disability index used to assess associated disabilty. Intraoperative data were document and patients followed up postoperatively for six months, by the same methods used for preoperative evaluation.

Results: Both groups were comparable regarding all studied variables, except signficant increase of symptoms duration in group A than group B $(4.45 \pm 1.09$ vs $3.28 \pm 0.924$ months, respectively). Also, there was signficant low back pain reduction in A than B group (1.23 \pm 0.586 vs $1.72 \pm 0.643$ ), at the six months of follow up. Finally, in both groups, low back and radicular pain was signficantly reduced when compared to preoperative values.

Conclusion: The use of lumbar fusion for the management of recurrent disc prolapse is an effective, and safe management option. It associated with more low back pain reduction.

Keywords: Low back pain; Discectomy; Lumber Interbody Fusion; Recurrent.

Disclosure: The authors have no financial interest to declare in relation to the content of this article. The Article Processing Charge was paid for by the authors.

Authorship: All authors have a substantial contribution to the article.

\section{INTRODUCTION}

The surgical treatment of herniated lumbar disc has advantages over the non-operative treatment and the long-term clinical outcomes of lumbar discectomy remain superior to the conservative treatment despite the re-operation rate is as high as $25 \%{ }^{1}$. Leven et al. ${ }^{2}$ reported that recurrent lumbar disc herniation was the indication for re-operation after primary discectomy in $62 \%$ of cases.

Despite recurrent lumbar disc herniation being a relatively common complication, there is debate about the optimal treatment. There are multiple surgical treatment options for recurrent lumbar disc herniation with the main two options consisting of revision lumbar discectomy and instrumented fusion. Determining the optimal surgical intervention is often challenging as there is no evidence demonstrating superiority of one approach over another. There are several concerns regarding revision discectomy without fusion. One concern is that there is some inherent instability that led to the recurrent lumbar disc herniation. Another concern is that revision discectomy may lead to more instability. Additional lamina and facet are resected to identify normal tissue plains to avoid incidental durotomy and neural injury ${ }^{3}$. The most recent lumbar fusion guidelines state that fusion is reasonable for treatment of recurrent lumbar disc herniation in the setting of instability, spinal deformity, or chronic low back pain ${ }^{4}$.

Posterior and posterolateral lumbar arthrodesis now includes fusion of bilateral transverse processes. The reported fusion rate of modern bilateral posterolateral fusion is $81-100 \%$ and clinical success rate is $60-98$ $\%$ regardless of the use of transpedicular fixation ${ }^{5}$. Circumferential fusion theoretically can release the compression on the disc space, increase fusion rate 
by adding an end plate, and improve correction of the deformity ${ }^{6}$

The strategies for circumferential fusion include anterior lumbar interbody fusion (ALIF), posterior lumbar interbody fusion (PLIF), and transforaminal lumbar interbody fusion (TLIF). The fusion rate can vary significantly from 74 to $98 \%$, and short- and long-term follow-up showed significantly improved clinical outcomes in patients who received PLIF versus posterolateral fusion 7 . However, PLIF requires a longer operating time and can be associated with greater blood loss, more tissue trauma from extensive tissue dissection, more tissue scarring, that induce neurological complications. Thus, it is important to elucidate whether the additional risk during the longer PLIF operation provides an improved outcome ${ }^{8}$.

\section{PATIENTS AND METHODS}

Population: 30 patients suffering from recurrent lumbar disc prolaps

Study Design: This is a prospective comparative study, patients are categorized in two equal groups by a closed envelope method of randomization; Group A: included patients who had interbody fusion added to the transpedicular screw, Group B: included patients who were subjected to transpedicular screws.

Setting: Al-Azhar University Hospitals, and AlMenshawy General Hospital.

Inclusion Criteria: Patients with single level recurrent lumbar disc suffering from either low back pain or radicular pain.

\section{Exclusion Criteria:}

Patients who have contraindication for general anethesia.

Patients with associated lumber canal stenosis.

Patients with spondylolisthesis.

\section{Preoperative assessment:}

\section{The preoperative data including:}

History, preoperative neurological examination as well as, oswestry disability index (ODI), visual analogue score (VAS), walking distance and Japanese Orthopedic Association score (JOA) for treatment for low back pain.

Radiology as preoperative MRI or CT and plain xrays (dynamic views) were done

Operative data included the site, the blood loss during operation, operative time and mode of fixation used, post-operative pain and neurological disability before and after surgery. We used Japanese Orthopaedic Association score ${ }^{9}$ and Oswestry disability index questionnaire (ODI) ${ }^{10}$ for assessment of outcome. Additionally, patients were asked about the walking distance, how far were they able towalk in meters before and after surgery. Each patient was asked to indicate his/her perceived pain intensity through visual analogue scale (VAS).

Neurological Examination: A focused neurological examination performed to identify any neurological deficit. Lower limb motor evaluation includes hip flexors, knee flexion and extension, dorsiflexion, plantar flexion, and great toe extension and flexion. Heel and toe walking also are tested to evaluate the strength of the tibialis anterior (foot dorsiflexion, L5) and gastrocnemius (foot plantar flexion, S1). Patellar and ankle deep tendon reflexes are evaluated. Sharp sensation is often tested with a pinprick in each of the dermatomes distributions. If the patient is describing any bowel or bladder incontinence, or impaired sensation, perianal sensation should be evaluated. Anal reflexes can be tested. The straight-leg test, which may be performed with the patient either seated or laying down, is a fair screening test for nerve root irritation. Local back examination searching for tenderness and paravertebral muscle spasm was also carried out.

\section{Consent for surgery:}

Lumber laminectomy and disc removal with lumbar pedicle screw fixation with inter body fusion consent includes discussing the operative procedure with the patient with its intended benefits of pain relief and possible improving function and symptoms of walk. Discussing Neurological deterioration, complications such as (Dural tear, infection, hematoma, nerve root injury).

Preoperative investigations: Complete Blood count (CBC), Bleeding profile (bleeding time), prothrombin time (PT), partial thromboplastin time (PTT), kidney function and liver function. ECG, Echocardiography (if indicated), Plain chest X-ray.

Specific imaging; Plain $\mathrm{x}$-ray films of lumbosacral spine (antero-posterior, lateral, and dynamic films "flexion/extension). With either one of the following: Computerized Tomography C.T. Magnetic resonance imaging MRI.

Anesthesia: General anesthesia in all of cases, Intravenous antibiotics should be given 30 minutes prior to incision.

Position: The patient position is prone on spinal frame, with the abdomen free and thespine flexed to open the inter-laminar spaces.

\section{Procedures:}

Bilateral laminectomy and discectomy: The incision was made longitudinally midline over the spinous processes. The dissection was carried down with electro cautery through the subcutaneous tissue until the thick white lumbosacral fascia was reached. Electro cautery was used to expose the posterior tip of the spinous process bilaterally. When the lamina has been reached, a periosteal elevator was used to scrape the Para spinal muscles laterally to the facet joints. Residual muscle fibers are removed from the lamina and facets with a large rongeur. A Kerrison punch was used to remove the inferior one third of the lamina above from medial to lateral. The ligamentum flavum was removed completely at this level with the bone nippler. The medial aspect of the inferior facet from the vertebrae above was removed and exposing the superior facet of the vertebrae below. The lateral recess was unroofed by removing the medial superior facet with different sized Kerrison punches. The superior facet was removed. Bluntnerve hook was used to palpate the margins of the foramen. The most superior tip of the superior articular facet was resected in performing the foraminotomy. The wound was irrigated, and homeostasis was maintained in the epidural space with bipolar electro cautery of the epidural veins then performing a decompression or a discectomy. 
Curetting disc material and cartilage from the vertebral endplate, final disc material is removed and endplates prepared. All nuclear disc material is removed to ensure good bone graft to vertebral bone contact.

Pedicle screw fixation: The location of the pedicles is identified by anatomical landmarks (pars inter articularis) and by radiography or image intensification fluoroscopy in the operating room. Use a pedicle finder, with a 20-degree medial inclination at L5, 10-degree inclination at L4, 5degree inclination at L3 and L2, and no inclination at L1.Follow the progress of the pedicle finder by feeling insidethe pedicle with a pedicle feeler and by checking with the fluoroscopy. The bone is generally decorticated and bone graft is placed between lamina and transverse process before final placement of screws.

Lumber inter body fusion: There are two different types of posterior interbody fusion procedures. The traditional PLIF procedure involves placing two small bone graft spacers, with gentle retraction of the spinal nerves and neurologic structures, one graft on each side of the interbody space (right and left). A TLIF (transforminal lumbar interbody fusion), involves placing only one bone graft spacer in the middle of the interbody space, without retraction of the spinal nerves. The PLIF technique includes performing a wide laminectomy and bilateral partial facetectomy to allow visualization and removal of the intervertebral disc. The TLIF technique includes performing a complete unilateral (one side only) facetectomy to allow visualization and removal of the intervertebral disc. Special distractor instruments are used to restore the normal height of the disc, as well as to determine the appropriate size spacer to be placed. A bone spacer (metal or peek spacers may also be used) is then carefully placed in the disc space. The Lumbar Cage is radiolucent and allows visualization of bony healing by normal plane radiographs. The cages are tightly packed with autologous bone graft and inserted into the disc space.

Follow up the patient: In this study we followed our patients immediate postoperative, one week after surgery and six months postoperative where we evaluated clinical and radiological finding including clinical examination (by assessing subjective symptoms such as (low back pain and radicular pain), clinical signs, outcome scores including the visual analogue score, Oswestry disability index, Walking distance, Japanese score and Length of postoperative hospital stay also Postoperative X-ray imaging after surgery for both groups of patients was evaluated.

Statistical analysis: Data entry and analyses were performed using SPSS statistical package version 10 (SPSS, Inc., Chicago, IL, USA). The quantitative data were presented as a mean and standard deviation. Paired t-test was conducted to evaluate the impact of surgery on the mean of outcome scores. The qualitative data were presented as number and percentage. The chi-square $\left(\chi^{2}\right)$ was used to find the association between variables of qualitative data. $\mathrm{P}$ value of $\leq 0.05$ and of $\leq 0.001$ indicate significant and highly significant results respectively.

\section{RESULTS}

In the current work, patients were mostly in their forties, with male sex predominance and slightly overweight. The most affected levels were L5-S1 follwoeid by L4-5. The associated cormobid conditions were smoking, diabetes mellitus, hypternsion, cardiac disease and previous operations (Table 1).

\begin{tabular}{|c|c|c|c|c|c|}
\hline \multicolumn{2}{|c|}{ Variable } & $\begin{array}{c}\text { Group } \\
\text { A } \\
(n=15)\end{array}$ & $\begin{array}{c}\text { Group } \\
\text { B } \\
(n=15)\end{array}$ & $\mathrm{t} / \chi^{2}$ & $\mathbf{P}$ \\
\hline \multicolumn{2}{|c|}{ Age (years) } & $\begin{array}{c}46.16 \pm \\
8.53\end{array}$ & $\begin{array}{c}44.72 \pm \\
9.14\end{array}$ & 0.446 & 0.659 \\
\hline \multirow{2}{*}{ Sex } & Male & $\begin{array}{c}11 \\
(73.3 \%)\end{array}$ & $\begin{array}{c}10 \\
(66.7 \%) \\
\end{array}$ & \multirow{2}{*}{0.159} & \multirow{2}{*}{0.691} \\
\hline & Female & $\begin{array}{c}4 \\
(26.7 \%) \\
\end{array}$ & $\begin{array}{c}5 \\
(33.3 \%) \\
\end{array}$ & & \\
\hline \multicolumn{2}{|c|}{ BMI $\left(\mathrm{kg} / \mathrm{m}^{2}\right)$} & $\begin{array}{c}24.82 \pm \\
5.77\end{array}$ & $\begin{array}{c}25.66 \pm \\
5.83\end{array}$ & 0.397 & 0.695 \\
\hline \multirow{3}{*}{$\begin{array}{c}\text { Affected } \\
\text { Levels }\end{array}$} & L3-4 & $\begin{array}{c}1 \\
(6.7 \%) \\
\end{array}$ & $\begin{array}{c}1 \\
(6.7 \%) \\
\end{array}$ & \multirow{3}{*}{0.164} & \multirow{3}{*}{0.912} \\
\hline & L4-5 & $\begin{array}{c}5 \\
(33.3 \%) \\
\end{array}$ & $\begin{array}{c}4 \\
(26.7 \%) \\
\end{array}$ & & \\
\hline & L5-S1 & $9(60 \%)$ & $\begin{array}{c}10 \\
(66.7 \%) \\
\end{array}$ & & \\
\hline \multirow{5}{*}{$\begin{array}{l}\text { Associated } \\
\text { Comoribid } \\
\text { Conditions }\end{array}$} & Smoking & $\begin{array}{c}8 \\
(53.3 \%) \\
\end{array}$ & $9(60 \%)$ & 0.136 & 0.713 \\
\hline & $\mathrm{DM}$ & $\begin{array}{c}5 \\
(33.3 \%) \\
\end{array}$ & $\begin{array}{c}7 \\
(46.7 \%)\end{array}$ & 0.556 & 0.456 \\
\hline & HTN & $6(40 \%)$ & $\begin{array}{c}7 \\
(46.7 \%)\end{array}$ & 0.136 & 0.713 \\
\hline & $\begin{array}{c}\text { Cardiac } \\
\text { diseases }\end{array}$ & $\begin{array}{c}1 \\
(6.7 \%) \\
\end{array}$ & $\begin{array}{c}2 \\
(13.3 \%) \\
\end{array}$ & 0.371 & 0.543 \\
\hline & $\begin{array}{c}\text { Previous } \\
\text { operations }\end{array}$ & $3(20 \%)$ & $\begin{array}{c}2 \\
(13.3 \%) \\
\end{array}$ & 0.240 & 0.624 \\
\hline
\end{tabular}

Table 1: Demographic data of the two studied groups

Both groups A and B are comparable regarding pain free interval, preoperative low pack pain, preoperative radicular pain, and disability index. Additionally, operative time, hospital stay and intraoperative blood loss did not differ significantly between grops. However, the symptom duration was significantly longer among group A than group B (Table 2). 


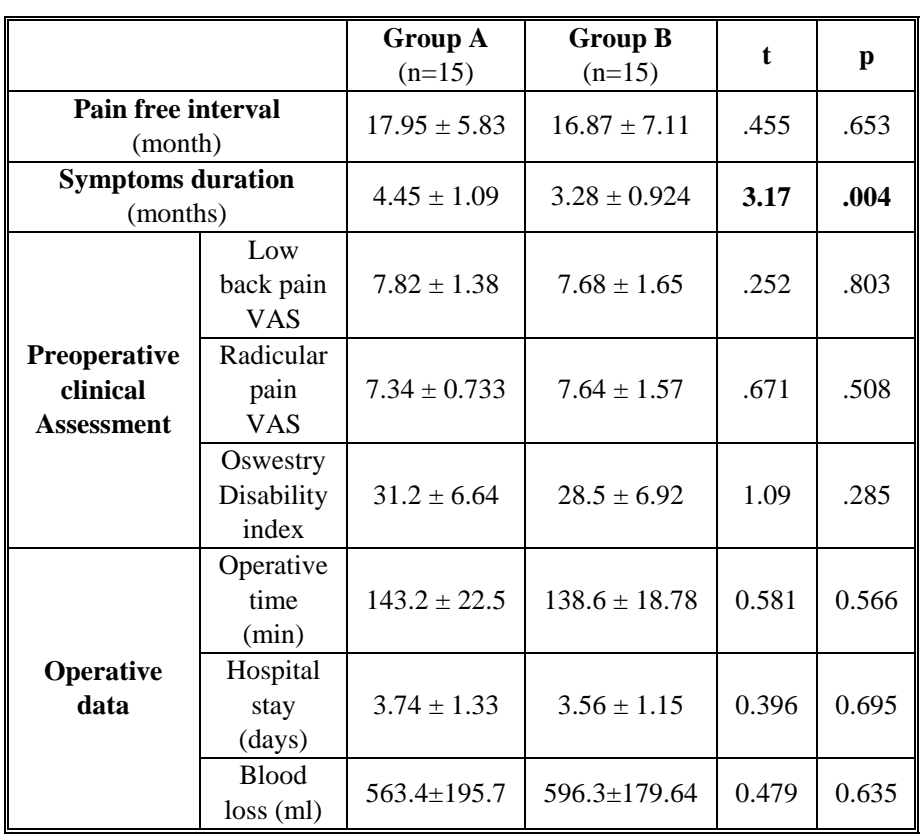

Table 2: Preoperative data, clinical assessment and operative data

Both groups showed significant improvement of low back pain and radicular pain after surgery than the preoperative values. Both were comparable regarding VAS score for low back pain except significant reduction in group A than group B at six months of follow up. Additionally, group A had significantly higher ODI at six months follow up (Table 3).

\begin{tabular}{|c|c|c|c|c|c|}
\hline & $\begin{array}{l}\text { Low back } \\
\text { pain VAS }\end{array}$ & $\begin{array}{c}\text { Group } \\
\text { A } \\
(n=15)\end{array}$ & $\begin{array}{c}\text { Group } \\
\text { B } \\
(n=15)\end{array}$ & $\mathrm{t}$ & $\mathrm{p}$ \\
\hline \multirow{4}{*}{$\begin{array}{c}\text { Low back } \\
\text { pain } \\
\text { (VAS) }\end{array}$} & Preoperative & $\begin{array}{c}7.82 \pm \\
1.38\end{array}$ & $\begin{array}{c}7.68 \pm \\
1.65\end{array}$ & 0.25 & 0.80 \\
\hline & Postoperative & $\begin{array}{c}2.54 \pm \\
0.747\end{array}$ & $\begin{array}{c}2.91 \pm \\
0.852\end{array}$ & 1.26 & 0.21 \\
\hline & $\begin{array}{l}\text { 6-months } \\
\text { follow up }\end{array}$ & $\begin{array}{l}1.23 \pm \\
0.586\end{array}$ & $\begin{array}{l}1.72 \pm \\
0.643\end{array}$ & 2.18 & $0.04 *$ \\
\hline & Fr test & $<0.001 *$ & $<0.001 *$ & & \\
\hline \multirow{4}{*}{$\begin{array}{l}\text { Radicular } \\
\text { pain } \\
\text { (VAS) }\end{array}$} & Preoperative & $\begin{array}{c}7.34 \pm \\
1.33\end{array}$ & $\begin{array}{c}7.64 \pm \\
1.57\end{array}$ & 0.67 & 0.50 \\
\hline & Postoperative & $\begin{array}{l}2.75 \pm \\
0.792\end{array}$ & $\begin{array}{c}2.83 \pm \\
0.882\end{array}$ & 0.26 & 0.79 \\
\hline & $\begin{array}{l}\text { 6-months } \\
\text { follow up }\end{array}$ & $\begin{array}{l}1.17 \pm \\
0.518\end{array}$ & $\begin{array}{l}1.33 \pm \\
0.562\end{array}$ & 0.81 & 0.42 \\
\hline & Fr test & $<0.001 *$ & $<0.001 *$ & & \\
\hline \multirow{4}{*}{ ODI } & Preoperative & $\begin{array}{c}31.2 \pm \\
6.64\end{array}$ & $\begin{array}{c}28.5 \pm \\
6.92\end{array}$ & 1.09 & 0.28 \\
\hline & Postoperative & $\begin{array}{c}26.58 \pm \\
4.22\end{array}$ & $\begin{array}{c}22.61 \pm \\
5.35\end{array}$ & 2.26 & $0.03 *$ \\
\hline & $\begin{array}{l}\text { 6-months } \\
\text { follow up }\end{array}$ & $\begin{array}{c}20.68 \pm \\
5.19\end{array}$ & $\begin{array}{c}17.22 \pm \\
5.59\end{array}$ & 1.76 & 0.09 \\
\hline & Fr test & $<0.001 *$ & $<0.001 *$ & & \\
\hline
\end{tabular}

Table 3: Low back pain VAS between the two studied groups

Table (4) revealed that, there was no significant difference between both groups regarding clinical, radiological outcome and overall outcome.

\begin{tabular}{|c|c|c|c|c|c|}
\hline & & $\begin{array}{c}\text { Group } \\
\text { A } \\
(n=15)\end{array}$ & $\begin{array}{c}\text { Group } \\
\text { B } \\
(n=15)\end{array}$ & $\chi^{2}$ & $\mathrm{p}$ \\
\hline \multirow{4}{*}{ Outcome } & Excellent & $\begin{array}{c}5 \\
(33.3 \%)\end{array}$ & $3(20 \%)$ & \multirow{4}{*}{1.9} & \multirow{4}{*}{.593} \\
\hline & Good & $\begin{array}{c}8 \\
(53.3 \%)\end{array}$ & $\begin{array}{c}7 \\
(46.7 \%)\end{array}$ & & \\
\hline & Fair & $\begin{array}{c}1 \\
(6.7 \%)\end{array}$ & $3(20 \%)$ & & \\
\hline & Poor & $\begin{array}{c}1 \\
(6.7 \%)\end{array}$ & $\begin{array}{c}2 \\
(13.3 \%)\end{array}$ & & \\
\hline \multirow{4}{*}{ Complications } & Dural tear & $\begin{array}{c}1 \\
(6.7 \%)\end{array}$ & $\begin{array}{c}2 \\
(13.3 \%)\end{array}$ & \multirow{4}{*}{0.63} & \multirow{4}{*}{0.89} \\
\hline & $\begin{array}{l}\text { Superficial } \\
\text { wound } \\
\text { infection }\end{array}$ & $\begin{array}{c}2 \\
(13.3 \%)\end{array}$ & $3(20 \%)$ & & \\
\hline & Discitis & $\begin{array}{c}1 \\
(6.7 \%)\end{array}$ & $\begin{array}{c}2 \\
(13.3 \%)\end{array}$ & & \\
\hline & $\begin{array}{c}\text { Neurological } \\
\text { deficit }\end{array}$ & 0 & $\begin{array}{c}1 \\
(6.7 \%)\end{array}$ & & \\
\hline \multirow{3}{*}{$\begin{array}{c}\text { Final clinical } \\
\text { and } \\
\text { radiological } \\
\text { Outcome }\end{array}$} & Fusion rate & $\begin{array}{c}12 \\
(80 \%)\end{array}$ & $\begin{array}{c}13 \\
(86.7 \%)\end{array}$ & 0.24 & 0.62 \\
\hline & $\begin{array}{c}\text { Patient } \\
\text { satisfaction }\end{array}$ & $\begin{array}{c}14 \\
(93.3 \%)\end{array}$ & $\begin{array}{c}13 \\
(86.7 \%)\end{array}$ & 0.37 & 0.54 \\
\hline & $\begin{array}{l}\text { Radiculopathy } \\
\text { improvement }\end{array}$ & $\begin{array}{c}13 \\
(86.7 \%)\end{array}$ & $\begin{array}{c}13 \\
(86.7 \%)\end{array}$ & 0.001 & 1 \\
\hline
\end{tabular}

Table 4: Outcome distribution between the two studied groups

\section{DISCUSSION}

The aim of our study was to compare the results of posterior interbody fusion combined with transpedicular screws versus the transpedicular screws alone in treatment of recurrent lumbar disc.

As regarding involved level distribution between the two studied groups, there was no sifnficant difference between groups. The most common involved level was L5-S1 $(60 \%$ and $66.7 \%) .{ }^{11}$ reported that, the commonest levels for a herniated disc are L4-5 and L5-S1. ${ }^{12}$ reported that, the area between the lumbar vertebral bodies and sacral vertebral bodies is a transition zone at increased risk of injury due to the change in biomechanics that occurs between these regions. Separating each vertebral body of the spine are pads of fibrocartilage based structures that provide support, flexibility, and minor load sharing known as the intervertebral discs. These are primarily composed of two layers, a soft, pulpy nucleus pulposus on the inside of the disc and a surrounding firm structure known as the annulus fibrosus.

In our study, there is no significant difference between the two studied groups as regard low back pain and radicular pain measured by VAS or disability measured by ODI. Technical feasibility is very important issue in comparing the outcome of surgical procedures. Our results indicates that no technical difficulties between both procedures and the priority will be for the neurological and functional outcomes. These results agree with. ${ }^{13}$, who reported that, there was no significant difference between fusion and fusion techniques in treating recurrent lumbar disc prolapse. Additionally. ${ }^{14}$, 
reported no differences between techniques regarding operative data.

There is a significant decrease in low back pain from preoperative to the sixth postoperative month in both groups Moreover, the two techiniques differ significantly at six months regarding low back pain VAS $(1.23 \pm 0.586$ in group A, and $1.72 \pm 0.643$ in group $\mathrm{B}, \mathrm{P}=0.038$ ). This may be attributed to the longer symptom duration in group A. Thus, the sense of pain relief was greater even if it is minimal. Also body fusion technique added more stability and reduced pain resulting from un-stability.

These results agree with. ${ }^{13}$, who reported nonsignficant difference of postoperative data, except postoperative low back pain and radicular pain which was significantly higher in the group of transpedicular screws alone.

Different techniques for interbody fusion were described. All techniques aimed to immobilize the painful degenerated spinal segments and restore disc height and root canal dimensions, as well as load bearing ability of the anterior structures . ${ }^{15-17}$

Although several comparative studies described in the literature between the discectomy and fusion techniques, only two comparative studies found in the literature that comparing discectomy alone versus discectomy with TLIF and transpedicular fixation ${ }^{18}$ ${ }^{19}$. El Shazly et al. ${ }^{18}$ conducted a prospective study to compare discectomy alone versus discectomy and fusion with TLIF or posterolateral interbody fusion (PLIF) and found no significant differences in outcomes between groups after a mean of 37 months of follow up. They concluded that, revision discectomy is effective for recurrent herniated lumbar disc. Fusion with revision discectomy decreased the postoperative low back pain, reduced the intraoperative risk of dural tear or neural damage and decreased the incidence of postoperative mechanical instability. TLIF and posterolateral fusion (PLF) have comparable results when used in revision discectomy.

Galal et al. ${ }^{19}$ compared the results of discectomy alone versus discectomy with TLIF and found no significant differences between group regarding preoperative VAS and Japanese Orthopaedic Association (JAO) scores, but postoperative back pain at the last follow-up was slightly higher in the discectomy group. However, the difference did not reach statistical significance. They concluded that, redo discectomy offers the required symptoms relief with an early recovery and return to work. Fusion can be advantageous for selected simple discectomy, not for all patients.

In a study done by Ye YP, et al. ${ }^{20}$ used VAS to assess the decline in low back pain, radicular pain, or leg pains in PLF- or PLIF-treated patients. The longterm pain relief significantly reduced in both treatment groups. Pooled differences in mean improvement of ODI after the operation revealed no significant difference in pain relief between the PLF and PLIF groups $(\mathrm{P}=0.856)$. However, results indicated that fusion rate was significantly greater in the PLIF group than that in the PLF group.
The current study is unique in its design, as it compared the posterior lumbar interbody fusion combined with transpedicular screws (group A) versus transpedicular screws alone (group B) in recurrent lumbar disc prolapse. We figured out a better pain tolerance in group A than in group B. However, postoperative pain decreased significantly when compared to preoperative values. Additionally, both grousp were comparable as regard to overall outcome and complicaitons rate.

Li $\mathrm{Z}$ et al. ${ }^{21}$ investigated the safety, effectiveness, and outcomes of TLIF for recurrent lumbar disc herniation after previous lumbar spine surgery. The level of recurrent disc was L4-L5 in 51 patients, L5$\mathrm{S} 1$ in 19 patients, and L3-L4 in three patients. The low back pain and leg pain, ODI, and JOA scores were signficanly improved at the final follow-up evaluation vistis than preoperative values. There were no significant complications. The results specify that TLIF could be considered as a safem an effective, and reliable treatment procedure for the recurrent lumber disc herniation (rLDH).

In a retrospective recent study, Wang and $\mathrm{Yu} \mathrm{Z.}{ }^{22}$ assessed total of 46 patients with $\mathrm{rLDH}$, and concluded that, percutaneous endoscopic lumbar discectomy (PELD) and TLIF are effective and safe after rLDH. PELD had shorter operative time, low amount of intraoperative blood loss and short postoperative hospitalization. However, it had a higher postoperative recurrence rate.

From all the aforementioned data we can conclude that, The use of lumbar fusion together with neural decompression for the management of recurrent disc prolapse cases is a popular surgical option, aiming to maintain disc height, ensure load sharing, and spinal stability. In our study, both techniques were comparable to each other regarding outcomes, pain tolerance and complications. But Posterior Lumbar Interbody Fusion Combined with Transpedicular Screws versus Transpedicular Screws was more technically feasible and enhanced reduced pain sensation in group A of patients.

\section{CONCLUSION}

The use of lumbar fusion for the management of recurrent disc prolapse is an effective, and safe management option. It associated with more low back pain reduction.

\section{REFERENCES}

1. Rogerson A, Aidlen J, Jenis LG. Persistent radiculopathy after surgical treatment for lumbar disc herniation: causes and treatment options. Int Orthop. 2019 Apr; 43(4):969-73.

2. Leven D, Passias PG, Errico TJ, Lafage V, Bianco K, et al. Risk Factors for Reoperation in Patients Treated Surgically for Intervertebral Disc Herniation: A Subanalysis of Eight-Year SPORT Data. J Bone Joint Surg Am. 2015 Aug 19;97(16):1316-25.

3. Hlubek RJ, Mundis GM Jr. Treatment for Recurrent Lumbar Disc Herniation. Curr Rev Musculoskelet Med. 2017 Dec;10(4):517-20. 政 
4. Wang JC, Dailey AT, Mummaneni PV, Ghogawala Z, Resnick DK, et al. Guideline update for the performance of fusion procedures for degenerative disease of the lumbar spine. Part 8: lumbar fusion for disc herniation and radiculopathy. $J$ Neurosurg Spine. 2014 Jul;21(1):48-53.

5. Alhammoud A, Schroeder G, Aldahamsheh O, Alkhalili K, Lendner $\mathrm{M}$, et al. Functional and Radiological Outcomes of Combined AnteriorPosterior Approach Versus Posterior Alone in Management of Isthmic Spondylolisthesis. A Systematic Review and Meta-Analysis. Int J Spine Surg. 2019 Jun 30;13(3):230-8.

6. Buser Z, Brodke DS, Youssef JA, Rometsch E, Park $\mathrm{JB}$, et al. Allograft Versus Demineralized Bone Matrix in Instrumented and Noninstrumented Lumbar Fusion: A Systematic Review. Global Spine J. 2018 Jun;8(4):396-412.

7. Tang L, Wu Y, Jing D, Xu Y, Wang C, Pan J. A Bayesian network meta-analysis of 5 different fusion surgical procedures for the treatment of lumbar spondylolisthesis. Medicine (Baltimore). 2020 Apr;99(14):e19639.

8. Li Y, Wu Z, Guo D, You H, Fan X. A comprehensive comparison of posterior lumbar interbody fusion versus posterolateral fusion for the treatment of isthmic and degenerative spondylolisthesis: A meta-analysis of prospective studies. Clin Neurol Neurosurg. 2020; 188:105594.

9. Yonenobu K, Abumi K, Nagata K, Taketomi E, Ueyama K. Interobserver and intraobserver reliability of the japanese orthopaedic association scoring system for evaluation of cervical compression myelopathy. Spine (Phila Pa 1976). 2001; 26(17):1890-4.

10. Smeets R, Köke A, Lin CW, Ferreira M, Demoulin C. Measures of function in low back pain/disorders: Low Back Pain Rating Scale (LBPRS), Oswestry Disability Index (ODI), Progressive Isoinertial Lifting Evaluation (PILE), Quebec Back Pain Disability Scale (QBPDS), and Roland-Morris Disability Questionnaire (RDQ). Arthritis Care Res (Hoboken). 2011 ; 63 Suppl 11:S158-73.

11. Müller SJ, Burkhardt BW, Oertel JM. Management of Dural Tears in Endoscopic Lumbar Spinal Surgery: A Review of the Literature. World Neurosurg. 2018 Nov; 119:494-99.

12. Akhaddar A, Belabyad S. Spontaneous Regression of Posterior Ring Apophysis Separation in Lumbar Spine. World Neurosurg. 2018 Nov;119:304-5.

13. Ahsan K, Khan SI, Zaman N, Ahmed N, Montemurro N, Chaurasia B. Fusion versus nonfusion treatment for recurrent lumbar disc herniation. $J$ Craniovertebr Junction Spine. 2021;12(1):44-53.

14. Papadopoulos EC, Girardi FP, Sandhu HS, Sama AA, Parvataneni HK, et al. Outcome of revision discectomies following recurrent lumbar disc herniation. Spine (Phila Pa 1976). 2006 Jun 1;31(13):1473-6.

15. Kou Y, Chang J, Guan X, Qiang C, Feng H. The endoscopic lumbar interbody fusion and minimally invasive transforaminal lumbar interbody fusion for the treatment of lumbar degenerative diseases : A Systematic review and Meta-analysis. World Neurosurg. 2021:S1878-8750(21)00804-4.

16. Said E, Abdel-Wanis ME, Ameen M, Sayed AA, Mosallam KH, et al. Posterolateral Fusion versus Posterior Lumbar Interbody Fusion: A Systematic Review and Meta-Analysis of Randomized Controlled Trials. Global Spine J. 2021: 21925682211016426

17. Reisener MJ, Pumberger M, Shue J, Girardi FP, Hughes AP. Trends in lumbar spinal fusion-a literature review. J Spine Surg. 2020 Dec;6(4):75261.

18. El Shazly AA, El Wardany MA, Morsi AM. Recurrent lumbar disc herniation: A prospective comparative study of three surgical management procedures. Asian J Neurosurg. 2013 Jul;8(3):13946.

19. Galal A, Elsayed A M, Ahmed O E. Recurrent Lumbar Disc Herniation: Is Fusion Necessary. The Internet Journal of Neurosurgery. 2019;15:1-7.

20. Ye YP, Xu H, Chen D. Comparison between posterior lumbar interbody fusion and posterolateral fusion with transpedicular screw fixation for isthmic spondylolithesis: a meta-analysis. Arch Orthop Trauma Surg. 2013 Dec; 133(12):1649-55.

21. Li Z, Tang J, Hou S, Ren D, Li L, Lu X, Hou T. Four-year follow-up results of transforaminal lumbar interbody fusion as revision surgery for recurrent lumbar disc herniation after conventional discectomy. J Clin Neurosci. 2015; 22 (2):331-7.

22.Wang A, Yu Z. Comparison of Percutaneous Endoscopic Lumbar Discectomy with Minimally Invasive Transforaminal Lumbar Interbody Fusion as a Revision Surgery for Recurrent Lumbar Disc Herniation after Percutaneous Endoscopic Lumbar Discectomy. Ther Clin Risk Manag. 2020;16:118593. 